\title{
THE SWISS NATIONAL PARK
}

\section{By Dr. G. N. Zimmerli, Superintendent}

The idea of a Swiss national park originated with the Swiss Society for Nature Research and this Socicty played the leading part in its realization. In 1906 the Society set up as part of its own organization a Swiss Nature Protection Commission and charged it to search for an area in Switzerland suitable for establishment as a reserve, in which all the animal and plant life could be protected against interference by man and so could be left entirely to the play of natural forces. It was not casy- to find in Switzerland a suitably large area which still retained its original characteristics, was virtually free from human settlement, and contained some wealth of fauna and flora. After a careful survey of the whole country it became clear that the most suitable region was the Lower Engadine, with its isolated valleys on the eastern border of the country. The district in which, at the beginning of the century, bears had still lived was the one in which primitive nature could be found in its truest state.

In 1909 the Swiss League for Nature Protection was founded in order to provide financial support for the national park and for the advancement of nature protection in general.

Between 1909 and 1911 the Nature Protection Commission of the Swiss Nature Research Society signed its first agreements with the communes of Zernez, S-chanf and Scuol for certain territory to be set aside as a nature reserve. In these first agreements it was stipulated that the rights and obligations embodied in them should later be transferred to the Swiss Confederation.

When the question arose of extending the national park by the inclusion of still further areas, it became necessary for the Confederation to participate. Based on an application made by the Nature Protection Commission in 1911, a message from the Federal Council in 1912 and $a$ supplementary message in 1913, the Federal Assembly enacted on Brd April, 1914, the Federal Decree on the establishment of a Siviss National Park in the Lower Engadine. After a thorough discussion, which was marked by a display of great enthusiasm, both the National Council and the Assembly of Cantons adopted the proposal almost unanimously. The necessary period having elapsed without any request for a referendum being submitted, the Federal Decree introducing this work of peace came into effect 
on the fateful 1st August, 1914, the day on which the first World War burst into flames around Switzerland.

The Idea of the National Park.-The basic conception of the national park, as embodied in the test of Article I of the Federal Decree, is that of keeping a piece of Swiss territory, with its plant and animal life, permanently free from the interference of human activities, leaving it open for natural development and at the same time available for scientific information and research. All economic utilization by man is prohibited unless carried on for the purpose of the park itself. Timberfelling, cattle-raising, hunting, fishing, collection of flowers and fruits, and building are all proscribed. But the national park is not an area closed to man; everyone may visit it free of charge, but must keep to the routes laid down in the Park Ordinance. These provide ample opportunity to wander through all parts of the protected area and to get to know the park.

The Legal and Financial Foundations.-The Federal Decree of 3rd April, 1914, which is really the foundation stone of the Swiss National Park, covers the following main points :-

It gives statutory effect to the creation of a Swiss National Park in the Lower Engadine as a public institution of the Confederation and defines its objects and character.

It empowers the Federal Council to conclude the necessary agreements : on the one hand with the communes concerned, on the other with the Swiss Nature Research Society and the Swiss League for Nature Protection.

It lays down the maximum level of the payments to be made annually by the Confederation.

The communes retain the title to the land in the area of the national park, but they have made it over to the Confederation for the establishment of a general reserve in return for annual payments. These agreements may be terminated unilaterally by the Confederation, at 25-year intervals, but not by the communes. (Special provisions apply in the case of the territory in the area of Scuol-Schuls-the so-called S-charl reservation-as the utilization agreement with this commune was made not by the Confederation but by the League for Nature Protection; it can be terminated by either side at 25year intervals.)

The present-day territory of the national park covers an area of about 160 square kilometres, making with the addition of the two adjoining hunting prohibition arcas, 190 square kilometres. It is in the following communes :- 


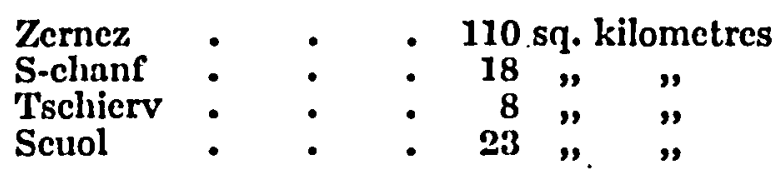

In an agreement concluded in 1913 between the Confederation, the Swiss Nature Research Society, and the Swiss League for Nature Protection, the responsibilities for the national park were apportioned as follows :-

The Confederation pays the annual compensation to the communes. The Federal Council exercises supervisory control over the national park and final decision on all matters concerning the park rests with it.

The Swiss League for Nature Protection meets the other expenses connected with the park (supervision, maintenance, administration, etc.).

The Swiss Nature Rescarch Society is responsible for scientific research.

An ordinance enacted by the Federal Council in 1044 contains provisions governing the organization and financial administration of the park. The Federal National Park Commission is responsible for supervision and administration of the park and its protection against human encroachments. This Commission has seven members, three of whom are appointed by the Federal Council and two each by the Nature Research Socicty and the League for Naturc Protection. Supervision over the park is excreised by the Superintendent with two park wardens and by fronticr guard stations in or near the park.

Scientific research in the park is carried out by the specinl commission set up by the Swiss Nature Rescarch Socicty, called the National Park Scientific Commission. This is organized in sub-commissions for metcorology, geology, botany, zoology and hydrology. Members of this commission visit the park every year. 'The Commission's first task was to take stock of the natural state of the park, a task which involved decades of work, as a basis on which to follow the changes taking place in a territory free from human interference and influence. Professor C. Schröter, who was for a long time president of the Commission, wrote the following: "The national park is an invaluable obscrvation ground, which is unique of its kind in that all disturbance of the balance of nature through human activitics is excluded. $\Lambda$ remarkable attempt to restore Nature to its wild state is being made there and one of the major tasks of the scientific observation is to follow every stage of this reversion to the wild. The complete protection of the park against 
destruction by men and cattle will transform it into a natural laboratory of inestimable value."

The results of scientific research and surveys in the national park are made known by the Commission in a special series of publications. Since 1028 there has been, in Chur, a national park museum containing material.from the park.

Wild Life in the National Park.-The majestic mountain landscape, the splendid alpine flora and the woods, all make a strong impact on any sensitive visitor to the park, but the main interest of most visitors is in the animals. What kinds of animals are there and how do they develop where man does not intervene to bring order or to help them, and where birds and beasts of prey have free rein ?

Anyone who goes to the park expecting at every step to sec game of all kinds, close by and in large numbers, will perhaps be disappointed. On the other hand, an observant person who takes his time and watches will see interesting sights and be convineed that the national park contains a gratifying amount of natural life.

The chamois is indigenous in all parts of the park. After a steady increase in the first few years, its numbers have remained approximately the same.

The red deer which was entirely absent from the Engadine at the time of the foundation of the national park, moved into the territory for the first time in 1915. Since then its numbers have increased to an extraordinary degree and the deer have spread to all parts of the park area. The conditions seem specially to favour this animal. In the summer and autumn the red deer can often be seen up to a height of 2,500 metres, far above the tree line; at the beginning of winter they regularly move nway into their winter territory, some of them into the woods of the Inn valley, others into the Münster valley and deep into the Vintschgau.

The roe deer appears in the park in moderate numbers. Unfortunately it suffers severely in hard winters. Possibly the increase in red deer kecps down the numbers of roe.

The Alpine ibex became extinct in Switzerland in about 1800 but, starting in 1911, ' was re-introduced. Those now in the national park were introduced in 1920, where they have increased slowly but steadily and have continued to spread. $\Lambda$ s the ibex was originally present in this region its re-introduction was planned when the park was founded and is the only exception to the principle of no human intervention.

The marmot inhabits chicfly the former Alpine pastures 
within the park. This is the animal which has best adapted itself to human visitors and it comes quite close to people on the approved paths.

Common and snow hares are also part of the park fauna, but they are rarely seen by the visitor.

Wildfowl are represented by the capercaillic, the black-cock and the ptarmigan. Rock partridge and hazel-hens are very rarely seen there.

The brown bear. $-A$ decade before the foundation of the national park, the last bear in Switzerland was shot in the Val Mingèr. It is often asked why bears and other wild animal species which are missing from the national park are not brought into it. The answer lies in the basic conception of the national park: nature should be left to have free sway without human interference; men should add nothing and take nothing away. Moreover, local inhabitants fear the introduction of large beasts of prey.

Foxes and smaller beasts of prey are present in the national park, but not in excessive numbers. 'The concern expressed in some quarters when the park was established, that the reservation would develop into a "fox farm" has proved to be without foundation.

The golden eagle inhabits the park and is often to be seen, but only one of the four known eyries is normally used.

The following table gives, in round figures, the estimated changes in the numbers of some of the park animals :-

$\begin{array}{rrrrrr} & & \text { Red Deer. } & \text { Roc. } & \text { Chamois. } & \text { Ibex. } \\ 1018 & - & 10 & 60 & 1,000 & -7 \\ 1020 & : & 20 & 00 & 1,100 & 7 \\ 1030 & - & 130 & 150 & 1,170 & 14 \\ 10.40 & - & 410 & 120 & 1,260 & 100 \\ 1050 & - & 660 & 80 & 1,200 & 180 \\ 105.1 & - & 600 & 40 & 1,300 & 200\end{array}$

The plants and animals in the national park are left entirely to natural development, so that both creative and destructive forces have free rein. 'The national park is not intended to be a carefully nursed game preserve and there is therefore no feeding of the animals. IHunting quarters have raised the question whether feeding stuffs should not be provided at least for the red deer. However, not only do the basic regulations of the national park forbid such a step, but there are also other reasons against it. During winter the park is subject to avalanches. Ought the deer which, every winter, following their sure instincts leave the park and its danger areas, to be tied there by the provision of feeding places? Would not any such places, with 
the great numbers of animals assembling there, provide breeding grounds for disease? And where are the places to which food could be taken? In winter large areas of the park are inaccessible.

Just as many foresters find the "confusion" of untended woodlands and the unused fallen timber in the park difficult to understand, so huntsmen may not like to think of the numbers of game which perish without being used. But there should not be an exaggerated idea of the number of dead game in the park. Of course, in winters of heavy snowfall many animals fall victims to avalanches, just as they do in other areas rich in game. On the other hand there has so far been no confirmation of the fear that here, where veterinary game control and other measures taken by man are entirely absent, there would be devastating outbreaks of game discases. Since its establishment the national park has been spared major animal epidemics. Only in isolated cases have dead game been found to have game diseases, such as strongylosis and nasal fly infestation.

Scientific research in the park covers its entire animal and plant life. Whilst zoologists have already advanced a long way in the study of small fauna, especially butterflies and other insects, they have still much to do in relation to birds and mammals. Large mammals and birds can only be observed in the open; they cannot be handled like beetles and ants. In addition, continued observation of the park all the year round is extremely desirable in order to study the natural life of the animals. The National Park Scientific Commission also wishes to devote itself to a thorough study of the interesting problems which relate to the habitat, the distribution, the development and the way of life of the animals in the national park.

The prophecy that the national park would be an El Dorado for poachers has happily turned out to be unfounded. Thanks to good supervision and also to respect for idealism which inspires the concept of the park, the hunters of the Grisons, even the unlicensed ones, have always kept clear of the area. The fact that the land adjoining the national park is hunted very heavily during September may perhaps be regretted, but cannot be prevented. Apart from a very few incursions over the boundary, which were the result more of unrestrained enthusiasm on the part of hunters than of wilful intent, it may be noted with satisfaction that not a single Swiss hunter has had to be prosecuted for a deliberate offence in the protected area. On the other hand, even in the first few years after the park was founded, and since then on various occasions, poachers from 
the neighbouring Livigno valley in Italy have crossed over into the park and this, as on several occasions, led to sharp exchanges of fire with our supervisory staff. But Italian nature protection and hunting organizations propose to establish a game reserve in the territory adjoining the Swiss National Park. Let us hope that the project is soon realized.

Since the large increase in the number of red deer, the problem of damage in the surrounding districts by animals from the park has become important. 'This damage can be considerably reduced by defensive measures such as fencing of particularly valuable crops and providing field guards during critical periods. The Federal National Park Commission has agreed with the commune of Zernez, the cattle-owners of the hamlet of S-charl and the owner of the Fuorn property, which is surrounded by the park, to pay contributions at fixed annual rates towards the cost of defensive measures.

Besides the scientific importance of the national park, its educational value should not be neglected. The visitor must leave the edelweiss where it grows, in the knowledge that it will give pleasures to all those who follow in his footsteps. He must watch the herd of chamois from the approved path not chase after it, so that the next people to come that way shall also have the chance of secing it. Thus people can learn in the park to think about the others who will come after them and to consider their interests.

The Swiss National Park is a broad scientific venture and symbolizes the awareness of nature of the Swiss people as a whole. May it always continue to do so. 